\title{
Pengaruh Sistem Zonasi pada Penerimaan Peserta Didik Baru dan Budaya Sekolah terhadap Mutu Pendidikan
}

\author{
Alpikar Alpikar ${ }^{1}$ \\ ${ }^{1}$ Sekolah Dasar Negeri Kabupaten Banyuasin, Indonesia
}

\section{Article Info}

Article history:

Received Jul 20 $0^{\text {th }}, 2021$

Revised Aug 12 $2^{\text {th }}, 2021$

Accepted Aug 30 ${ }^{\text {th }}, 2021$

\section{Keyword:}

Sistem zonasi

Penerimaan peserta didik baru

Budaya sekolah

Mutu pendidikan

\begin{abstract}
Mutu pendidikan merupakan masalah yang terus menerus membutuhkan perhatian dalam penyelenggaraan pendidikan di Indonesia. Rilis dua tahunan PISA yang menguji kemampuan literasi baca tulis dan numerik peserta didik pada tingkat dasar masih menunjukkan hasil yang kurang memuaskan. Penelitian yang bercorak kuantitatif ini membahas masalah pengaruh sistem zonasi pada PPDB dan budaya sekolah terhadap mutu pendidikan. Subjek penelitiannya adalah sekolah dasar negeri se-kecamatan Betung Kabupaten Banyuasin. Triangulasi data dilakukan dengan angket serta observasi dan studi dokumentasi. Hasil penelitian menunjukkan terdapat pengaruh signifikan sistem zonasi pada PPDB dan budaya sekolah terhadap mutu pendidikan SD Negeri se-kecamatan Betung Kabupaten Banyuasi
\end{abstract}

(C) 2021 The Authors. Published by IICET.

This is an open access article under the CC BY-NC-SA license

(https://creativecommons.org/licenses/by-nc-sa/4.0

\section{Corresponding Author:}

Alpikar, A.,

Sekolah Dasar Negeri Kabupaten Banyuasin, Indonesia

Email: alpikar@gmail.com

\section{Pendahuluan}

Persoalan yang menjadi beban bagi dunia pendidikan Indonesia saat ini salah satunya adalah mutu pendidikan. Berbagai rilis mengenai kemampuan literasi maupun karakter peserta didik baik tingkat nasional maupun global menunjukkan hasil yang masih memperihatinkan. Dalam skala global, rilis PISA menunjukkan bahwa kemampuan pelajar Indonesia dalam bidang literasi baca tulis maupun numerik berada pada posisi memprihatinkan.

Berkaitan dengan input atau peserta didik yang masuk ke lembaga pendidikan atau sekolah, sejak tahun 2017 pemerintah telah mengatur sistem penerimaan peserta didik baru (PPDB) atau istilah sebelumnya penerimaan siswa baru (PSB) melalui sistem zonasi. Menteri pendidikan saat itu, sebagaimana dikutip oleh Septiawan (Pikiran-rakyat.com, 21 Juni 2019), mengatakan meskipun PPDB sistem zonasi banyak kendala, namun kebijakan tersebut akan tetap dilanjutkan.

Sistem zonasi mengatur mengatur bagaimana distribusi tidak hanya peserta didik, tetapi juga guru (pendidik) dan tenaga kependidikan. Sebagaimana telah banyak diteliti sebelumnya (wijayanti dan Sutapa, 2015, Aristo, 2019 dan Safarah dan Wibowo, 2019), fakta bahwa pemerataan pendidikan di Indonesia masih menjadi kendala bagi upaya peningkatan mutu pendidikan. 
Sesuai uraian di atas, maka penelitian ini akan membahas pengaruh sistem zonasi pada PPDB dan budaya sekolah terhadap mutu pendidikan di SD Negeri se-kecamatan Betung.

\section{Sistem Zonasi}

Zonasi sendiri sesungguhnya istilah yang berkaitan dengan tata ruang. Undang-undang nomor 262007 tentang Penataan Ruang, misalnya mengatakan bahwa peraturan zonasi pada dasarnya adalah suatu alat untuk pengendalian yang mengatur tentang persyaratan pemanfaatan ruang dan ketentuan pengendaliannya yang disusun untuk setiap blok/zona peruntukan.

Sistem zonasi telah banyak diterapkan di negara-negara yang sistem pendidikannya sudah jauh lebih maju seperti di Jepang. Mashudi (2019: 190) mengutip pernyataan Menteri Pendidikan dan Kebudayaan Muhadjir Effendy yang menyebutkan, negara maju yang telah lebih dulu menerapkan sistem zonasi yakni Jepang. Menurutnya, Jepang merupakan negara dengan sistem pendidikan zonasi terbaik, meski dalam proses pemerataan zonasi Jepang membutuhkan waktu sekitar 30 tahun.

Meskipun klaim keberhasilan penerapan sistem zonasi di Jepang sudah diakui dunia, kekurangan tetap saja ditemukan. Penelitian Akabayashi (2006) sebagaimana dikutip oleh Pradewi dan Rukiyati (2019:29) yang mengatakan bahwa implementasi sistem zonasi meningkatkan kualitas pendidikan di sekolah-sekolah perkotaan dengan meningkatnya pilihan, akan tetapi kontribusinya terhadap prestasi rata-rata siswa sangat kecil dibandingkan dengan upaya penyaringan siswa yang ditingkatkan.

Pada tahun 2018, sistem zonasi dilaksanakan dengan berdasarkan permendikbud nomor 14 tahun 2018. Pasal 16 peraturan menteri ini mengatur lebih rinci mengenai sistem zonasi. Dari $100 \%$ daya tamping sekolah terhadap peserta didik baru, $90 \%$ nya masih dialokasikan untuk calon peserta didik dalam radius terdekat dari sekolah. 5\% nya untuk jalur prestasi (PMPA) dan sisanya 5\% untuk jalur perpindahan siswa karena mengikuti orang tua atau karena bencana alam/sosial.

\section{Budaya Sekolah}

Sekolah merupakan sebuah bentuk dari organisasi. Budaya Organisasi (sekolah), sebagaimana dikemukan oleh Fattah (2019: 35-36) dapat dirunut dari empat komponen yaitu:

1. Karakter orang-orang yang membentuk atau berada dalam organisasi tersebut

2. Nilai-nilai etika dan kepercayaan pemimpin dan manajemen puncak organisasi

3. Distribusi hak-hak kepemilikan dalam organisasi

4. Struktur organisasi.

Sedangkan Purwoko (2018: 151) mengatakan budaya sekolah adalah hubungan kerja antara sesama guru, antara guru dengan kepala sekolah, antara guru dengan tenaga kependidikan lainnya serta antar dinas merupakan wujud dari lingkungan yang kondusif. Dari uraian di atas, dapat diringkas pengertian budaya sekolah adalah nilai-nilai yang membentuk suasana hubungan antar seluruh komponen yang ada di sekolah dalam rangka mencapai visi misi sekolah.

\section{Mutu Pendidikan}

Sallis (2012: 267) berpendapat bahwa mutu pendidikan adalah fungsi dari dari proses pembelajaran yang efektif, kepemimpinan, peran serta guru, peran serta siswa, manajemen, organisasi, lingkungan fisik dan sumber daya, kepuasan pelanggan sekolah, dukungan input dan fasilitas, dan budaya sekolah. Pendidikan yang bermutu mengacu pada dua hal, yaitu proses dan hasil (Umar dan Ismail, 2017: 16.)

Zubaidah (2015: 183) menuliskan beberapa komponen yang terkait dengan mutu pendidikan yaitu : mutu input (Siswa, sarana prasarana, SDM), mutu proses (Mutu Guru Mutu pembelajaran, Mutu belajar siswa, Mutu Manajerial), Mutu output (Akademik dan Non Akademik). Aspek-aspek input, proses dan output ini dapat juga menjadi indikator mengapa selama ini usaha peningkatan mutu pendidikan kerap berakhir kurang memuaskan.

Agustina, Djasmi dan Suntoro (2016: 2-3) mendefinisikan mutu sekolah secara operasional sebagai kemampuan sekolah dalam mengolah secara operasional dan efisien terhadap komponen-komponen yang berkaitan dengan sekolah. Mereka mengidentifikasi beberapa faktor yang mempengaruhi mutu pendidikan adalah kepemimpinan, iklim sekolah serta kinerja guru.

\section{Hipotesis Penelitian}

Hipotesis adalah dugaan sementara tentang suatu masalah yang kebenarannya perlu diuji. Untuk menguji kebenaran hipotesis tersebut maka dibutuhkan data yang kemudian diolah dengan rumus statistik. Tujuannya 
adalah untuk mendapatkan kesimpulan, apakah hipotesis diterima atau ditolak. Adapun rumusan hipotesis dalam penelitian ini adalah:

1. Terdapat pengaruh signifikan sistem zonasi terhadap mutu pendidikan di kecamatan Betung.

2. Terdapat pengaruh signifikan budaya sekolah terhadap mutu pendidikan di kecamatan Betung.

3. Terdapat pengaruh signifikan sistem zonasi dan budaya sekolah secara bersama-sama terhadap mutu pendidikan di kecamatan Betung.

\section{Metode}

Penelitian ini berupa penelitian kuantitatif yang dilaksanakan di SD Negeri se-kecamatan Betung dan berlangsung antara bulan September sampai Desember 2020. Populasi pada penelitian ini terdiri dari 27 sekolah dasar negeri dengan jumlah guru sebanyak 415 guru (berdasarkan data dapodik diknas Kecamatan Betung tahun 2020). dengan menggunakan rumus slovin didapatkan sampel sebanyak 204 guru dari 13 sekolah. Alat pengumpul data yang digunakan adalah angket/kuesioner, observasi serta studi dokumentasi. Uji validitas dan reliabilitas angket dilakukan pada 20 responden untuk mendapatkan butir angket yang valid dan reliabel sebagai instrumen pengumpul data dalam penelitian ini. Skala penilaian yang digunakan dalam penelitian ini adalah skala likert. Dalam kuesioner ini, peneliti menghilangkan alternatif jawaban ragu-ragu karena alternatif jawaban ragu-ragu menimbulkan kecenderungan responden untuk memilih alternatif jawaban tersebut. Jenis pernyataan ini digunakan dalam kuesioner ini ada dua macam yaitu pernyataan positif dan pernyataan negatif.Teknik analisis data dalam penelitian ini menggunakan teknik analisis data korelasi sederhana dan regresi berganda dengan bantuan perangkat lunak pengolah data statistika. Adapun tahap pelaksanaan analisis meliputi: (1) Analisis Deskriptif, (2) Uji Persyaratan Analisis, dan (3) Uji Hipotesis (Sugiyono, 2012:289).

\section{Results and Discussions}

Hasil uji regresi berganda ditampilkan pada tabel berikut ini:

Tabel $1<$ Hasil Uji Regresi Berganda $>$

\begin{tabular}{|c|c|c|c|c|}
\hline & \multicolumn{2}{|c|}{$\begin{array}{c}\text { Tabel } 4 . \\
\text { Uji Regresi Berganda Coefficients }\end{array}$} & & \\
\hline & $\begin{array}{l}\text { Unstandardized } \\
\text { Coefficients }\end{array}$ & $\begin{array}{l}\text { Standardized } \\
\text { Coefficients }\end{array}$ & & \\
\hline Model 1 (Constant) & $\begin{array}{l}\text { B Std. Error } \\
8.088\end{array}$ & 11.290 Beta & & \\
\hline Sistem zonasi & .489 & -.019 & .5325 .311 & .000 \\
\hline Budaya sekolah & .406 & .825 & $.460 \quad 4.593$ & . .000 \\
\hline
\end{tabular}

Berdasarkan hasil uji regresi berganda di atas, maka diperoleh nilai konstanta persamaan regresi (a) sebesar 11.290 dan nilai koofisien variabel bebas (b1) sebesar -0.019 dan nilai (b2) sebesar 0, 825, maka diperoleh persamaan regresi sebagai berikut.

$\mathrm{Y}=\mathrm{a}+\mathrm{b} 1 \mathrm{X} 1+\mathrm{b} 2 \mathrm{X} 2$

$\mathrm{Y}=11.290-0,019 \mathrm{X} 1+0.825 . \mathrm{X} 2$

Artinya, mutu pendidikan mengalami peningkatan secara positif melalui sistem zonasi dan budaya sekolah. Untuk mengetahui kebenaran pengujian hipotesis, maka dilakukan uji simultan dengan menggunakan uji $\mathrm{F}$ untuk mengetahui pengaruh variabel sistem zonasi dan budaya sekolah terhadap variabel mutu pendidikan. Adapun kriteria pengujian adalah sebagai berikut:

1. Jika nilai probabilitas (signifikan) $<0.005$, maka $\mathrm{H}_{03}$ ditolak

2. Jika nilai probabilitas (signifikan) $>0.005$, maka $\mathrm{H}_{03}$ diterima Kemudian untuk uji $\mathrm{F}$, kriteria pengujian adalah sebagai berikut.

a. $\mathrm{H}_{\mathrm{a} 4}$ diterima jika $\mathrm{F}_{\text {hitung }}>\mathrm{F}_{\text {tabel }}$

b. $\mathrm{H}_{04}$ diterima jika $\mathrm{F}_{\text {hitung }} \leq \mathrm{F}_{\text {tabel }}$

Adapun hipotesis penelitian adalah sebagai berikut:

1. $\mathrm{Ha}_{3}$ : Terdapat pengaruh yang signifikan secara bersama-sama antara sistem zonasi dan budaya sekolah terhadap mutu pendidikan di SD Negeri se Kecamatan Betung.

2. Ho3: Tidak terdapat pengaruh yang signifikan secara bersama-sama antara sistem zonasi dan budaya sekolah terhadap mutu pendidikan di SD Negeri Se Kecamatan Betung. 


\section{Simpulan}

The conclusion are: 1) Terdapat pengaruh antara sistem zonasi terhadap mutu pendidikan SD Negeri se kecamatan Betung. 2) Terdapat pengaruh antara budaya sekolah terhadap mutu pendidikan SD Negeri sekecamatan Betung. 3) Terdapat pengaruh secara bersama-sama antara sistem zonasi dan budaya sekolah terhadap mutu pendidikan SD Negeri se-kecamatan Betung.

\section{Referensi}

Agustina. Djasmi, S., Suntoro, I., (2016). Pengaruh Kepemimpinan Kepala Sekolah Iklim Kinerja Guru terhadap Mutu Pendidikan Lampung Tengah. Jurnal manajemen Mutu Pendidikan. Vol. 4 No. 1. 1-16

Fattah, Hussein. (2019). Kepuasan kerja dan Kinerja Pegawai (Budaya organisasi, perilaku Pemimpin, dan efikasi Diri). Jogyakarta: El Matera

Pradewi, G.I. dan Rukiyati. 2019. Kebijakan Sistem Zonasi dalam Perspektif Pendidikan. JMSP (Jurnal Manajemen dan Supervisi Pendidikan) Volume 4 Nomor 1, 28-34

Sallis. (2012). Total quality management in education. Yogyakarta: IRCiSoD.

Sugiyono. (2012). Metode Penelitian (Kuantitatif Kualitatif dan R\&D). Bandung: Alfabeta.

Umar, M. dan Ismail, F. (2017). Peningkatan Mutu Lembaga Pendidikan Islam (Tinjauan Konsep Mutu Edward Deming dan Joseph Juran). Jurnal Pendidikan Islam Iqra' Vol. 11. No. 2. 1-24

Zubaidah, Siti. (2015). Pengaruh Budaya Sekolah dan Motivasi Kerja Guru Terhadap Mutu Pendidikan di SMK N 1 Pabelan. Prosiding Seminar Nasional Pendidikan UNS \& ISPI Jawa Tengah 2015. 